\title{
THE CLIMATE INDUCED VARIATION OF THE CONTINENTAL BIOSPHERE : A MODEL SIMULATION OF THE LAST GLACIAL MAXIMUM
}

\author{
P. Friedlingstein ${ }^{1,3}$, C. Delire ${ }^{2}$, J.F. Müller ${ }^{3}$ and J.C. Gérard ${ }^{2}$
}

Abstract. A simplificd three-dimensional global climate model was used to simulate the surface tempcrature and precipitation distributions for the Last Glacial Maximum (LGM), 18000 years ago. These fields were applied to a bioclimatic scheme wich paramelerizes the distribution of eight vegetation types as a function of biotemperature and annual precipitation. The modcl predicts a decrease, for LGM compared to present, in forested area balanced by an increase in desert and undra extent, in agreement wilh a reconstruction of the distribution of vegetation based on paleodata. However, the estimated biospheric carbon content (phytomass and soil carbon) at LGM is less reduced than in the reconstructed onc. Possible reasons for this discrepancy are discussed.

\section{Introduction}

Analysis of air bubbles in ice cores has clearly established that the atmospheric concentration of carbon dioxide during the Last Glacial Maximum, 18000 ycars ago. was about $75 \mathrm{ppm}$ less than the preindustrial (interglacial) level. A larger content of carbon in the terrestrial biosphere during glacial periods could be a possible cause of this low atmospheric $\mathrm{CO}_{2}$ concentration. Transfer of carbon from the biosphere to the atmosphere could thus explain the rise in amospheric $\mathrm{CO}_{2}$ concentration between LGM and the preindustrial times.

Using a general circulation model and a bioclimatic schemc, Prentice and Fung (1990) estimatcd that the amount of carbon in the vegetation and soils at LGM was approximately equivalent to the present interglacial. They found that $200 \mathrm{Gl}$ of carbon were stored by vegetation and soils on land exposed by the low sea level $18 \mathrm{kyr}$ ago. This additional carbon pool at LGM has almost exactly counterbalanced the lower amount of carbon stored by vegetation and soils on the present land area. They concluded that carbon uransfer between the biosphere and the atmosphere should not have been a dominant factor in the large atmospheric $\mathrm{CO}_{2}$ level change between glacial and interglacial events. In contrast, Adams et al. (1990), basing their estimates on palynological, pedological and sedimentological data, found that the amount of carbon stored in the biosphere may have been smaller by more than $1000 \mathrm{Gl}$ of carbon at LGM than during the Holocene, corresponding to a doubling in the terrestrial carbon content from LGM to present interglacial. This result has important implications on the ability of the ocean to store the large amounts of carbon that may have been transfered to the atmosphere-biosphere system since the LGM. The contrast between the two sets of results was already present in the reconstruction they made of the vegetation distribution at the LGM. According to Adams et al. (1990), drier vegetation types having a low carbon storage per unit area, such as desert and arid scrub, were much more extensive $18 \mathrm{kyr}$ ago than they are currently. Moist climate types (with high carbon storage) were almost absent from the large areas which they occupy today. In contrast, following the simulation made by Prentice and Fung (1990), the driest vegetation types would have covered a smaller area than today.

The aim of this study is to simulate the climate and the distribution of vegetation types at LGM and to compare it to the reconstruction

\footnotetext{
${ }^{1}$ Université Libre de Bruxelles, ${ }^{2}$ Institut d'Astrophysique - Université de Liège, ${ }^{3}$ Institut d'Aéronomie Spatiale - Bruxelles

Copyright 1992 by the American Geophysical Union.

Paper number 92GL00546

$0094-8534 / 92 / 92 \mathrm{GL}-00546 \$ 03.00$
}

made by Adams et al. Discrepancies between this work and that of Prentice and Fung are also discussed.

\section{The armospheric model and the bioclimatic scheme}

The model used for this work is the quasi-three dimensional global climate model developed by Sellers $(1983,1985)$. Description of this model and discussion of its ability to reproduce the present climate can be found in the original papers. Most of the major features of the sea level pressure and tempcrature lields are quile well simulated. As it is the case for most GCMs, the simulated precipitation field presents some discrepancies with the obscrved field. For present conditions, it yields a global average sea level temperature of $289.6 \mathrm{~K}$ and total precipitation of $2.3 \mathrm{~mm} /$ day.

An empirical model of the biosphere has been developed. Il predicts the global distribution of the vegctation types and the main carbon pools and fluxes from two climatic variables: the annual precipitation and the biotempcrature (the biotemperature is the mean annual temperature (in ${ }^{\circ} \mathrm{C}$ ) considering only positive monthly temperatures). Starting from the World Ecosystem Database of Olson et al. (1985) which includes 52 ecosystems on a $0.5^{\circ} \times 0.5^{\circ}$ resolution grid, we define eight broad vegetation types (numbers in parenthesis refer to Olson's classification): perennial ice (17,69-71), deser and semi-desert (49-51), tundra $(53,63)$, coni Terous forest $(20-23,57,60-62)$, deciduous forest $(24-26,46,48,56)$, grassland and shrubland $(40-42,47,52,59,64)$, seasonal tropical forest $(27,28,32,43)$ and evcrgrcen tropical forest $(29,33)$. Present-day $5^{\circ} \times 5^{\circ}$ annual precipitation and biotemperanure distributions were derived from monthly mean climatological fields of precipitation (Shea, 1986) and surface temperature (Trenberth et al., 1988). The relationship between the spatial distribution of each vegetation type and the two climatic variables was then determined empirically. Each vegetation type is allowed to exist within a defined domain of precipitation and biotemperalure (Table 1). The vegetation distribution predicted by this bioclimatic scheme, for present-day precipitation and temperaturc fields, agree with Olson's database. The limited resolution of the model gencrate some discrepancies when compared with the data, particularly in mountainous regions. Net primary productivity (NPP). phytomass and soil organic carbon pool are calculated as follows. The Miami model (Lieth, 1975) is modified by expressing NPP as the minimum value of two lunctions, the first depending on mean annual precipitation and latitude, the second depending only on biolemperalure.

$$
\begin{array}{rlr}
\mathrm{NPP} & =\min \left(\mathrm{f}_{B T}, \mathrm{f}_{P}\right) & \\
\text { with } & & \\
\mathrm{f}_{B T} & =69.1875 \times \mathrm{BT} & \text { if } \mathrm{BT}<8^{\circ} \mathrm{C} \\
& =1350 \times \times\left(1 .+\exp \left(\frac{1}{1315-0119 \times B T}\right)\right) & \text { if } \mathrm{BT}>8^{\circ} \mathrm{C} \\
\mathrm{f}_{P} & =1125 \times\left(1 .-\exp \left(-6.64 \times 10^{-4} \times \mathrm{P}\right)\right) & \text { in the tropics } \\
& =1350 \times\left(1 .-\exp \left(-6.64 \times 10^{-4} \times \mathrm{P}\right)\right) & \text { in other regions } \\
\mathrm{BT} & =\text { biotemperature expressed in }{ }^{\circ} \mathrm{C} & \\
\mathrm{P} & =\text { annual precipilation expressed in } \mathrm{mm} / \mathrm{y} \\
\mathrm{NPP} & =\text { net primary production expressed in } \mathrm{gC} / \mathrm{m}^{2} / \mathrm{y} .
\end{array}
$$

The parameters were adjusted to fit the global NPP distribution given by Fung et al. (1983). The global annual NPP predicted by the model is $53 \mathrm{glC} / \mathrm{yr}$. The living phylomass (Table 2, Column 4) is calculated as the product of NPP and the mean residence time for carbon in herbaceous and woody biomass in the different vegetation types derived from Goudriaan cl al. (1984). Values adopted are listed in Table 3. Finally, soil carbon is inferred from Post et al's study (1982) which relates this variable to biotemperature and annual precipitation. 
Table 1. Minimum biotemperature $\left(\mathrm{BT}_{m}\right)$ and maximum biotemperature $\left(\mathrm{BT}_{M}\right)$ (in ${ }^{\circ} \mathrm{C}$ ) for different annual precipitation levels (in $\mathrm{mm} / \mathrm{yr}$ ) allowing the existence of each vegetation type (refer to Table 2, Column 1 ).

\begin{tabular}{|c|c|c|c|c|c|c|c|c|c|c|c|c|c|c|c|c|}
\hline \multirow{2}{*}{$\frac{\text { Vegetation type }}{\text { Precipitations }}$} & \multicolumn{2}{|c|}{1} & \multicolumn{2}{|c|}{2} & \multicolumn{2}{|c|}{3} & \multicolumn{2}{|c|}{4} & \multicolumn{2}{|c|}{5} & \multicolumn{2}{|c|}{6} & \multicolumn{2}{|c|}{7} & \multicolumn{2}{|c|}{8} \\
\hline & $\mathrm{BT}_{m}$ & $\mathrm{BT}_{M}$ & $\mathrm{BT}_{m}$ & $\mathrm{BT}_{M}$ & $\mathrm{BT}_{m}$ & $\mathrm{BT}_{M}$ & $\mathrm{BT}_{m}$ & $\mathrm{BT}_{. U}$ & $\mathrm{BT}_{m}$ & $\mathrm{BT}_{M}$ & $\mathrm{BT}_{m}$ & $\mathrm{BT}_{M}$ & $\mathrm{BT}_{m}$ & $\mathrm{BT}_{M}$ & $\mathrm{BT}_{n}$ & $\mathrm{BT}_{M}$ \\
\hline 10 & 0. & 5.0 & 4.0 & - & & & & & & & & & & & & \\
\hline 50 & 0. & 5.0 & 4.0 & - & 0.6 & 4.0 & 2.5 & 4.0 & & & & & & & & \\
\hline 60 & 0. & 0.6 & 4.0 & - & 0.6 & 4.0 & 2.5 & 4.0 & & & & & & & & \\
\hline $\begin{array}{r}80 \\
100\end{array}$ & 0. & 0.6 & 4.0 & $=$ & 0.6 & 4.0 & 2.5 & 4.0 & & & & & & & & \\
\hline $\begin{array}{l}100 \\
130\end{array}$ & $\begin{array}{l}0 . \\
0 .\end{array}$ & $\begin{array}{l}0.8 \\
1.0\end{array}$ & $\begin{array}{l}4.0 \\
4.0\end{array}$ & $\overline{-}$ & $\begin{array}{l}0.6 \\
0.6\end{array}$ & $\begin{array}{l}4.0 \\
4.0\end{array}$ & $\begin{array}{l}2.5 \\
2.5\end{array}$ & $\begin{array}{l}4.1 \\
4.5\end{array}$ & & & $\begin{array}{l}4.0 \\
4.3\end{array}$ & $\begin{array}{l}4.0 \\
6.0\end{array}$ & & & & \\
\hline 160 & 0. & 1.0 & 7.0 & " & 0.6 & 4.0 & 2.5 & 4.7 & & & 4.4 & 28.0 & & & & \\
\hline 200 & 0. & 1.0 & 10.0 & - & 0.6 & 4.0 & 2.5 & 5.0 & & & 4.5 & - & & & & \\
\hline 230 & 0. & 1.0 & 15.0 & - & 0.6 & 4.1 & 2.5 & 5.5 & & & 4.7 & - & & & & \\
\hline 300 & 0. & 1.0 & & & 0.6 & 4.2 & 2.5 & 6.5 & & & 5.0 & - & & & & \\
\hline 400 & 0. & 0.8 & & & 0.6 & 4.4 & 2.7 & 7.2 & & & 6.2 & - & & & & \\
\hline 500 & 0. & 0.7 & & & 0.6 & 4.6 & 3.0 & 8.0 & 8.5 & 8.5 & 7.2 & - & & & & \\
\hline 600 & 0. & 0.7 & & & 0.6 & 4.7 & 3.2 & 8.7 & 8.5 & 17.6 & 8.8 & 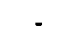 & & & & \\
\hline 700 & 0. & 0.7 & & & 0.6 & 4.7 & 3.4 & 9.2 & 9.1 & 18.7 & 17.4 & - & & & & \\
\hline 800 & 0. & 0.7 & & & 0.6 & 5.2 & 3.5 & 10.0 & 9.5 & 19.5 & 19.1 & - & 20.8 & 20.8 & & \\
\hline 900 & 0. & 0.7 & & & 0.6 & 5.2 & 3.8 & 11.0 & 9.9 & 20.0 & 20.2 & 26.6 & 20.0 & 35.0 & & \\
\hline 1000 & 0. & 0.7 & & & 0.6 & 5.2 & 4.0 & 11.5 & 10.0 & 20.7 & 21.4 & 25.7 & 20.0 & - & & \\
\hline 1100 & & & & & 0.6 & 5.3 & 4.2 & 11.5 & 10.0 & 20.8 & 23.4 & 23.4 & 20.2 & - & & \\
\hline 1300 & & & & & 0.6 & 5.5 & 4.6 & 11.5 & 10.0 & 21.1 & & & 20.7 & - & & \\
\hline 1500 & & & & & 0.6 & 5.5 & 4.7 & 11.5 & 10.0 & 21.2 & & & 20.8 & - & 23.0 & 23.0 \\
\hline 2000 & & & & & 0.6 & 5.5 & 4.8 & 11.5 & 10.0 & 21.3 & & & 21.0 & - & 23.0 & 35.0 \\
\hline 3000 & & & & & 0.6 & 5.5 & 5.0 & 11.5 & 10.0 & 21.3 & & & 21.1 & 23.0 & 22.7 & 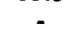 \\
\hline
\end{tabular}

\section{Glacial climate simulation}

In order to simulate the climate of the Earth during the Last Glacial Maximum, 18000 years ago, some inpul paramelers and boundary conditions of the model were changed. The orbital parameters were taken from Berger (1978). The almospheric $\mathrm{CO}_{2}$ concentration was decreased to $200 \mathrm{ppm}$, in agrecment with the $\mathrm{CO}_{2}$ measurements from the Vostok icc core (Bamola cl al., 1987). Coastlines were modified assuming a sea levcl drop of $130 \mathrm{~m}$ (Climap, 1976). Sea ice and snow cover were taken from Climap for Fcbruary and August. Their annual cycle was approximated by a sine function with February and August values taken as extrema. The model was run to steady state for the present day and the LGM conditions. The difference between the simulated temperature ficld for the present and for the LGM was then added to the observed temperature field above mentioned. The same was done for the precipitation field. In this way, the simulated climate change was rooted in the observed climatology and the effect of the systematic errors of the model was minimized. In this simulation, the global temperature and precipitation rates at LGM were decreased by $3.13 \mathrm{~K}$ and $0.35 \mathrm{~mm} /$ day respectively. The land temperature dropped by $5.13 \mathrm{~K}$ in the northern hemisphere and by $1.13 \mathrm{~K}$ in the southem hemisphere. The $130 \mathrm{~m}$ sea level drop increased the continental area by 23 millions $\mathrm{km}^{2}$. The high latitudes werc most influenced by the LGM conditions as far as temperature is concerned. The decrease in precipitation over land affected mostly South America, Africa and Australia. The modeled temperature and precipitation fields were then used to calculate the biotemperature and annual precipitation distributions. These two ficlds, simulated at a $10^{\circ} \times 10^{\circ}$ resolution, were linearly intcrpolated on a $5^{\circ} \times 5^{\circ}$ grid and applied to the bioclimatic scheme described before.

\section{Simulated glacial biospherc}

Global maps of the simulated distribution of vegetation are presented in Figure 1. Following this simulation, the boreal vegetalion types were shifted towards lower latitudes with tundra occupying areas presently covered by conifcrous, and to a lesser extent, deciduous forests. This is basically a result of the reduced temperatures over these regions. Lower precipitation rates $18 \mathrm{kyr}$ years ago in Australia and Sahel explain why deserts were more extensive and grasslands and shrublands less extensive. Decreased precipitation was also responsible for the reduction in seasonal tropical forests which are replaced by grasslands and shrublands in Southem Africa. Howcver, seasonal tropical forests expanded on lands that are immersed today in South East Asia and Occania. Evergreen tropical forests were almost absent from the equatorial regions where they are to be found now. As evergreen tropical foresis have high NPP, the reduction in their size has a strong negative effect on the total living phytomass al glacial time (Column 5, Table 2). Total living phytomass is also strongly dependent on the redistribution of conifcrous forest and tundra, since the latter is much less carbon-productive than the lormer. On the other hand, additional phylomass (about $120 \mathrm{GLC}$ ) was present due to the

Table 2. Comparison of the extent (in $10^{\circ} \mathrm{km}^{2}$ )and carbon content (in $\mathrm{GtC}$ ) of the terrestrial biosphere for present natural and LGM conditions (Antarctica excluded).

\begin{tabular}{llcccccc}
\hline & Vegetation type & \multicolumn{2}{c}{ Area } & \multicolumn{2}{c}{ Phylomass } & \multicolumn{2}{c}{ Soil carbon } \\
& & Present & LGM & Present & LGM & Present & LGM \\
\hline 1 & Perennial ice & 3 & 23 & 0 & 0 & 0 & 0 \\
2 & Desert and semidescrt & 16 & 24 & 1 & 1 & 31 & 34 \\
3 & Tundra & 10 & 21 & 25 & 34 & 124 & 236 \\
4 & Coniferous forest & 24 & 12 & 236 & 91 & 307 & 159 \\
5 & Deciduous forest & 16 & 14 & 237 & 204 & 163 & 144 \\
6 & Grassland and shrubland & 36 & 34 & 30 & 27 & 240 & 239 \\
7 & Scasonal tropical forest & 20 & 25 & 225 & 276 & 236 & 312 \\
8 & Evergreen tropical forest & 11 & 6 & 147 & 64 & .196 & 103 \\
& Total & 136 & 159 & 901 & 697 & 1297 & 1197 \\
\hline
\end{tabular}


Table 3. Fractions of herbaceous and woody biomass and mean residence time by vegetation type (numbers refer to Table 2, Column 1).

\begin{tabular}{|c|c|c|c|c|c|c|c|c|}
\hline Vegetauion type & 1 & 2 & 3 & 4 & 5 & 6 & 7 & 8 \\
\hline Herbáccous ratio & 1. & 1. & 0.155 & 0.0265 & 0.0265 & ]. & 0.0225 & 0.0225 \\
\hline Woody ralio & 0. & 0. & 0.845 & 0.9735 & 0.9735 & 0. & 0.9775 & 0.9775 \\
\hline Residence time in herbaccous biomass (in years) & 1.5 & 1. & 1.5 & 2. & 2. & 1. & 1. & 1. \\
\hline Residence time in woody biomass (in ycars) & $\cdot$ & - & 50 . & 60. & 60. & - & 30. & 30. \\
\hline
\end{tabular}

larger land area resulting from the lower sca level. Allogether, the phytomass accumulated by the vegetation al LGM was $23 \%$ lower than at present time. Soil organic carbon pool calculated as mentioned before does not present a significant dificrence between the present and glacial period (Column 7, Table 2).

\section{Discussion and conclusions}

An interesting comparison is possible with the reconstruction by Adams et al. (1990). The general trends between the two approaches agree, showing an increase al LGM in the areas covered by low vegetation types and deserts at the expense of forests. The Adams et al. results are more drastic than those in our study: they estimated a relative change of $-52 \%,+20 \%$ and $+98 \%$, with Antarctica, ( to compare with $-20 \%,+20 \%$ and $+136 \%$ in the present study, without Antarctica) for areas covered by forest, low vegetation types and deserts (Antarctica included), respectively. Due to this important shift from high to low carbon content vegctation types, the amount of terrestrial carbon at LGM is significantly smaller in their study. They estimated a total decrease of $1071 \mathrm{GlC}$ (if wetlands and peatlands are not considered), whereas we modeled a smaller drop of 300 $\mathrm{GtC}$ (Figure 2). Reasons for this difference may probably be found in the simulated LGM climate, especially the precipitation field. Consistently with other atmospheric models (Rind, 1987), the simplified model used herc seems to overcstimate the amount of water available for vegetation. Parlicularly, precipitation rates seem to be too high in intra-tropical regions to cull off the forested areas as in the Adams's study. To test this assumplion, the annual precipitation freld at LGM,

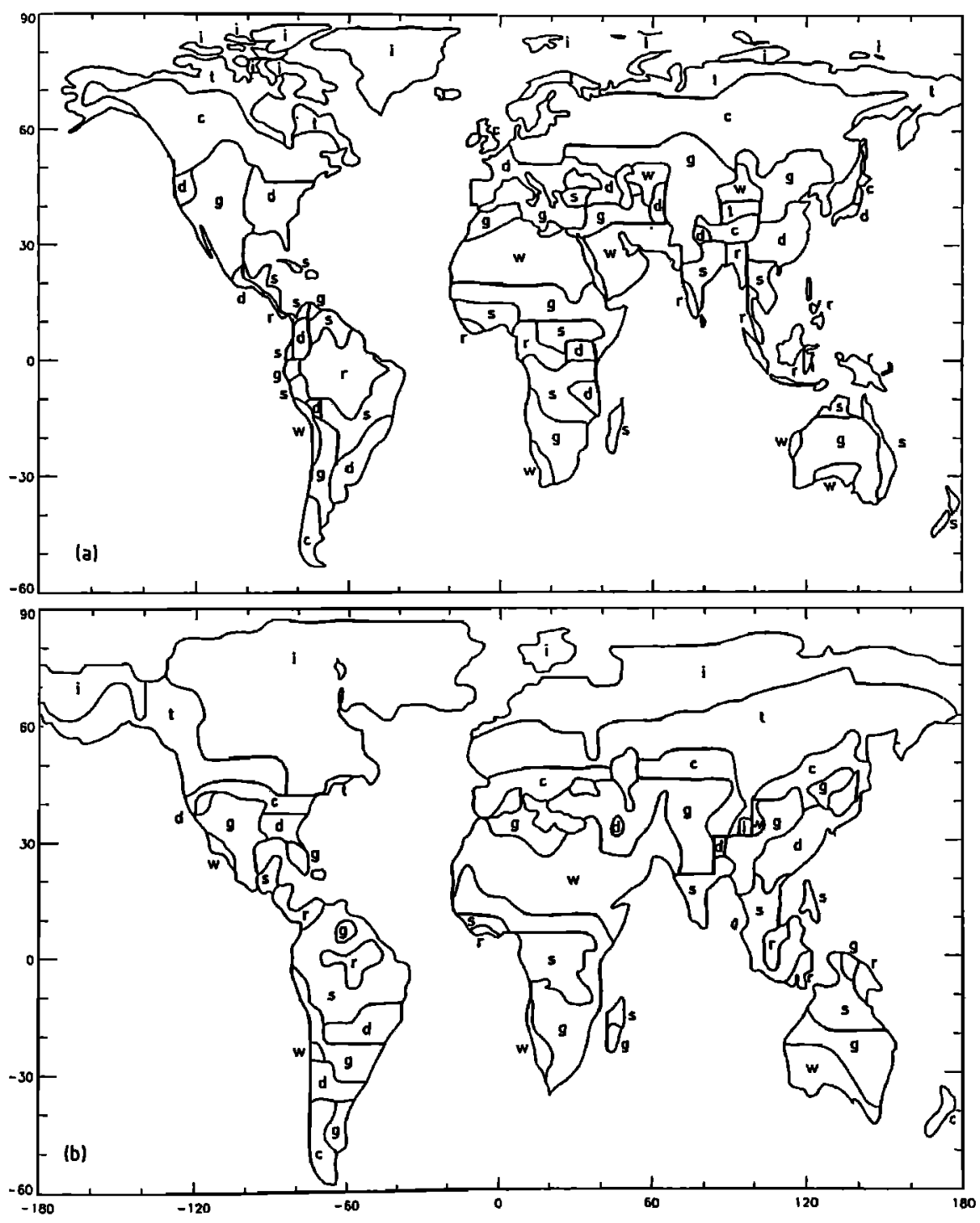

Fig. 1. (a). Simulated present day distribution of vegetation types: perennial ice [i], warm desert [w], grassland and shrubland [g], tundra [t], coniferous forest $[c]$, deciduous forest [d], seasonal tropical forest $[s]$ and evergreen tropical forest $[r]$. (b). Same for Last Glacial Maximum. 


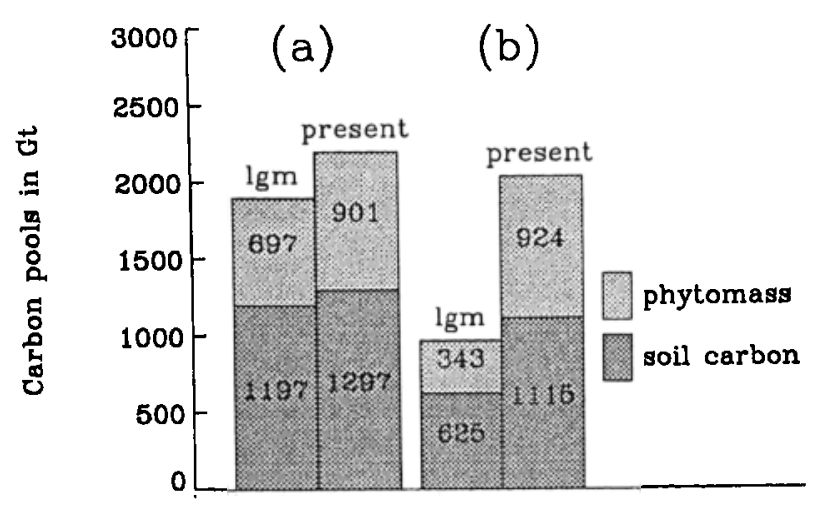

Fig. 2. Living phytomass and soil carbon content for present day and LGM conditions: (a) this work, (b) Adanis ct al. (1990) (without wetlands and peatlands).

estimated from January and July distributions simulated by the NCAR CCMO (Kutzbach and Guctler, 1986), was applicd to the bioclimatic scheme. The resulting distribution of vegetation is similar to the one obtained with the simplified GCM, except for the equatorial regions where the presence of evergrecn tropical forest as exiensive as today is simulated. This can be explained by the CCMO's steep gradient of the precipitation field between the tropics and the equator, allowing large tropical deserts neighbouring important moist climate types around the equator. Exccssive precipitation rates may also account for the slightly larger carbon pool al LGM than today as estimated by Prentice and Fung (1990).

Another limitation of both our and Prentice and Fung's study results from the assumption that the bioclimatic scheme developed for present climate remains valid for LGM conditions, i.e. the hypothesis that precipitation and biolemperature are the dominant factors in the vegetation "struggle for life". Low atmospheric $\mathrm{CO}_{2}$ content could further reduce the phylomass in a non negligible way. The productivity of the biosphere and hence the phytomass and the soil carbon at the LGM would be reduced by a factor of about two if the parameterization of the Osnabrick model (Esser, 1987) was used to take into account the "defertilization" $\mathrm{CO}_{2}$ cffect. Moreover, the bioclimatic scheme assumes that the vegetation distribution is in equilibrium with climatc. Since the last glaciation lasted more than 10000 years, this equilibrium was probably reached. But this may not be the case when considering fastcr climalc changes. Studies of the vegetation distribution of the next century require a dynamical model of vegetation including, among other faclors, the role of soils.

Our results, i.e. a low biospheric carbon content at LGM, combined with the low atmospheric $\mathrm{CO}_{2}$ concentration, suggest that the oceans should have played an important role in the carbon storage during the glacial to interglacial transitions, as also revealed by deep-sea core analysis (Shackleton, 1983).

Acknowledgments. Wc thank Pr. W. Scllcrs tor his help in the use of the simplified Global Climatc Model and P. Bchling for providing outputs of the NCAR CCM0 nuns for LGM conditions. Useful discussions with, G. Brasscur, D. Erickson, H. Faurc, B. Holland and R. Keeling are gratefully acknowledged. The authors are grateful to the Belgian Institute for Encouragement of Industrial and Agricultural Scientific Research (IRSIA) (PF and CD) and the Belgian Fund for Scientific Rescarch (FNRS) (JFM and JCG) for financial support. Part of this work was supported by the Belgian National Impulse Programmes "Global Change" and "Information Technologies
- Supercomputing" of the Belgian State - Prime Minister's Service Science Policy Office.

\section{References}

Adams, J.M., H. Faure, L. Faure-Denard, J.M. McGlade and FI Woodward, Increase in terrestrial carbon storage from the Last Glacial Maximum to the present, Nature, 348, 711-714, 1990.

Barnola, J.M., D. Raynaud, Y.F. Korotkevich and C. Lorius, Vostok ice core provides 160000 years record of atmospheric $\mathrm{CO}_{3}$ Nature, 329, 408-414, 1987.

Berger, A., Long-tcrm variations of daily insolation and quatemary climate changes, J. Atmos. Sci., 35, 2362-2367, 1978.

Climap project members, The surface of the ice-age Earth, Science. 191, 1131-1137, 1976.

Esser, G., Sensitivity of global carbon pools and Muxes to human and potential climatic impacts. Tellus, 39 B, 245-260, 1987.

Fung, I., K. Prentice, E. Malthews, J. Lerner and G. Russel, Thre dimensional model study of atmospheric $\mathrm{CO}_{3}$ response to sessonal exchanges with the terrcstrial biosphere. J. Geophys. Res., 88, 1281-1294, 1983.

Goudriaan, J. and P. Ketncr, A simulation study for the global carbon cycle including man's impact on the biosphere, Clim. Change, 6. 167-192, 1984.

Kutzbach, J.E. and P.J. Gucller, The influence of changing ortitul paramcicrs and surlace boundary conditions on climate simulations for the pasi 18000 years. J. Almos. Sci., 43, 1726-1759, 1986.

Lieth, H., Modeling the primary productivity of the world, in Primary productivity of the biosphere, editcd by Licth, H., and R.H. Whittaker, pp. 237-263, Springer-Verlag, New York, 1975.

Olson, J.S., J.A. Watts and L.J. Allison, Major world ecosystem complexes ranked by carbon in live vegetation. A data base. ORNL-5862, Oak Ridge National Laboratory, Oak Ridge. Tenn, 164 pp., 1985.

Post, W.M., W.R. Emanucl, P.J. Zinke and A.G. Stangenberger, Soil carbon pools and world life \%ones, Nature, 298, 156-159, 1982

Prentice K. and Fung I., The sensitivity of terrestrial carbon storage to climate change, Nalure, 346, 48-51, 1990.

Rind, D., Components of the ice age circulation, J. Geophys. Res., 92, 4241-4281, 1987.

Sellers, W., A quasi threc dimensional climate model, J. Clim. Appl. Meteorol., 22, 1557-1574, 1983.

Sellers, W., The effect of a solar perturbation on a global climate model, J. Clim. Appl. Meteorol., 24, 770-776, 1985.

Shackleton N.J., M.A. Hall, J. Line and Cang Shuxi, Carbon isotope data in corc V19-30 confirm reduccd carbon dioxide concentration in the ice agc atmosphere, Nature, 306, 319-322, 1983.

Shea, D.J., Climatological atlas: 1950-1979, NCAR Technical Note, NCAR/TN-269 +STR, 1986.

Trenberth, K.E. and J.G. Olson. ECMWF global analyses 1979-1986: Circulation Statistics and Data Evaluation, NCAR Technical Note, NCAR/TN-30()+STR, 1988.

P. Friedlingstein and J.F. Müller, Institut d'Aćronomie Spatiale, 3, avenue circulaire B-1180 Bruxelles -Belgium

C. Delire and J.C. Gćrard, Institut d'Astrophysique, Universilé de Liège, 5, avenue de Cointc B-4000 Ličge - Bclgium.

(received : January 20, 1992;

revised : March 4, 1992;

accepted : March 4, 1992.) 